\title{
犬の肺移植における一酸化窒素供与体 : FK409の効果について
}

\author{
須 納 瀬
}

は じめに

虚血再灌流倠害は肺移植直後化必発する肺水腫の主な 原因とされ，拒絶反応と並んで移植後のグラフト機能を 左右する重要な因子である. 虚血再灌流傷害においては, 反応の過程で様及な chemical mediator が傷害の増悪と 軽快に関与し，傷害が重篤なときには最終的に primary non-function 等の臓器障害につながる. その反応に関連 した物質の一つとして一酸化音素 (NO) が知られて㧍 り,重要な役割を果たすものとして椂々な研究がなされ ている.

NO はアルギニンのグアニジド基が酸化されて L-シ トルリンへと転換されるときに同時に生成される物質 で，NO 合成酵素（NOS）がこの反応を触媒している， NOS は eNOS, nNOS, iNOS の 3 種類が同定されて扔り, それぞれのNOSにより合成されたNOが, その状況に 応じて多彩な役割を果たすことが知られている。

虚血再灌流傷害時は, eNOSを介した反応により恒常 的に血管内皮細胞加ら産生された NO が, 生体機能の維 持槣与し, 細胞に保護的に作用することが知られる. 一方で, 種及のストレス刺激を誘因としてiNOSを介し た反応によりマクロファージから大量に産生された NO が, 生体に対する有害反応に関与し, 傷害的维く.

このように, NO は生体に対して保護的あるいは傷害 的记作用するという2 面性を有することが知られて扔 り, 今回はこの NOの保護的な作用について実験的に検 証することとした。

われわれは犬の左脑移植モデルで, NO 供与体として FK409 (FK) を投与して, 虚血再灌流傷害に対する効果 を検討した。

\section{犬の肺移植における一酸化窒素供与体； FK409投与の実験}

【対象と方法】8-14kg の雑種成犬を用いた。ドナー
豊 ${ }^{1}$

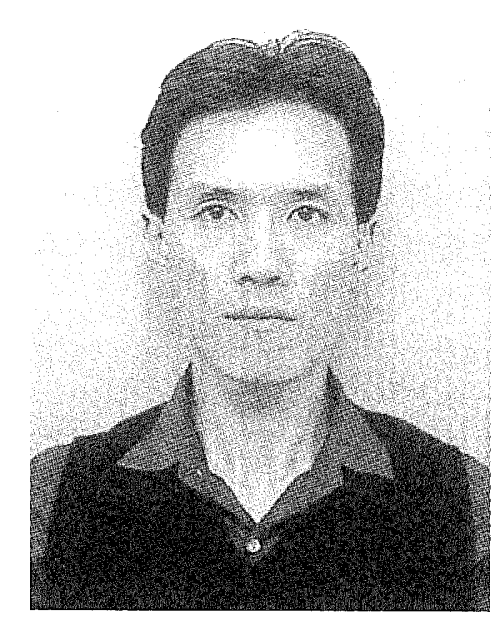

の左肺は $4^{\circ} \mathrm{C} の$ Euro-collins 液で灌流した後に摘出し て, 同液に 8 時間単純浸漬保存をした.レシピエントで は左肺を摘出後に, ドナーより摘出し保存したグラフト 肺を同所性に移植した。実験群を 2 群に分けた。 FK 群 $(\mathrm{n}=5)$ には, ドナーの血行遮断 30 分前より遮断時まで, およびレシピエントの再灌流 15 分前より 45 分後まで, FK $(5 \mu \mathrm{g} / \mathrm{kg} / \mathrm{min})$ を持続的に静注して, 対照群 $(\mathrm{n}=5)$ には溶解液 (生理食塩水) を同様に投与した. ドナーの血 行遮断前, およびレシピエントの再灌流 30 分後に左肺 動脈圧 (L-PAP), 左肺血管抵抗 (L-PVR), 動脈血酸素分 圧 $\left(\mathrm{PaO}_{2}\right)$, 肺胞気動脈血酸素分圧較差 $\left(\mathrm{A}-\mathrm{aDO}_{2}\right)$ を測定 した.また, 肺組織を病理学的に検討し, 併せ多形核好中 球 $(\mathrm{PMN})$ 浸潤を顕微鏡下に計測した. 更に, 経時的に血 中の NO 濃度, およびエンドセリン (ET)-1 濃度を測定 した. 再灌流 6 時間後に, 生体内で肺血流 $\left.{ }^{99 \mathrm{~m}} \mathrm{Tc}-\mathrm{MAA}\right)$, および換気 $\left({ }^{133} \mathrm{Xe}\right)$ シンチグラフィーを施行した.

【結 果】再灌流 30 分後の L-PAP, L-PVR 值は FK 群で有意に $(\mathrm{p}<0.05)$ 低值で, $\mathrm{PaO}_{2}, \mathrm{~A}-\mathrm{aDO}_{2}$ 值は有意に $(\mathrm{p}<0.05)$ 良好であった. 組織学的にもFK 群で肺胞や間 質の浮腫が軽度で, PMN 浸潤も有意に $(\mathrm{p}<0.05)$ 少な かった，以上より，FK の保護的な作用により移植肺の虚

1 群馬県前橋市昭和町3-39-22 群馬大学大学院医学系研究科臟器病態外科学 
血再灌流傷害が軽減されたことが示唆された．血中NO 濃度は, 対照群では再灌流後に低下するのに対し, FK 群 では FK 投与中に NO 濃度が高值に保たれていた。 また， 血中 $\mathrm{ET}-1$ 濃度は FK 群で有意に $(\mathrm{p}<0.05)$ 低値であっ た.これにより, FK の保護的な作用は直接的な NOの産 生と, NOを介した ET-1の抑制によるものと考元られ た. シンチグラフィーでは対照群のグラフト肺には ${ }^{99 \mathrm{~m}} \mathrm{Tc}$ -MAA と ${ }^{133} \mathrm{Xe}$ が殆ど取り込まれないが, FK 群ではグ ラフト肺に良好に集積した。 2 日生存率は FK 群が $100 \%$, 対照群が $40 \% て ゙, F K$ 群が有意に $(\mathrm{p}<0.05)$ 良好 であった，よって，臨床的にも肺の機能が保たれ，また， 生存率が改善することが示された。

【考 察】NO は虚血再灌流傷害の初期において, 活 性酸素の除去, 血小板の凝集の抑制, 好中球の凝集, 遊走, および活性化の抑制，血管内皮の透過性立進の抑制，血 管平滑筋の弛緩等の作用を有し, 最終的に傷害の軽減に 寄与する。

恒常的に血管内皮加産生されている内因性のNO は，再灌流と同時に活性酸素が大量に発生する際にその 多くが酸化 (不活性化) されてしまい, 相対的な NOの欠 乏状態になる, 再灌流直後にNO を補うことは, 活性酸 素による血管内皮障害と, 続発する微小循環障害や好中 球浸潤を抑制する上で有効である。本実験において, NO 濃度は再灌流後に対照群では低下したが, FK群では高 值に保たれていた。これにより FK 投与によるNOの維 持が，再灌流傷害の軽減に寄与したと考えられた。また， $\mathrm{NO}$ と拮抗し，内皮細胞障害の指標とされる ET-1 が抑 制されたことや，虚血再灌流傷害における second attack の主体とされ, 傷害の悪化因子とされる好中球浸潤が抑
制されたことも，NOによる効果と考えられた，

以上より NO 供与体 (FK409) 以肺移植に抢汀る虚血 再灌流傷害の軽減に有効である.

\section{現状ならびに今後の展望}

NO 供与体を投与する実験の後に, iNOS の選択的阻害 剤を投与して, 肝の虚血再灌流傷害が軽減され, iNOS の 発現が抑制されていることを確認した。また，組織中の iNOS と eNOS の発現を免疫染色で調べるのに加えて, Western blotting，およびRT-PCR 法で, 定量的に末梢血 㧍よび組織中のiNOS と eNOS の発現を測定している. そこで, 更なる実験として iNOS と eNOS が虚血再灌流 時に果たしている役割を分子生物学的に解析し, eNOS のみを増加させればよいのか，あるいは eNOS を増加さ せiNOSを減少させるのがよいのか等について検討中で ある。すな和ち，実験群をNO donor 投与群，iNOS 阻害 剤投与群, NO donor とiNOS 阻害剂との併用群扔よび 対照群とに分けiNOS と eNOSの発現を調べている.こ のように, NOを target とした虚血再灌流傷害のメカニ ズムとその治療について今後とも研究を行っていく予定 である。

謝辞

平成 17 年度北関東医学会奨励賞を頂き, 学会役員の 先生方ならびに研究に対してご指導を賜りました群馬大 学大学院医学系研究科臟器病態制御系病態循環再生学講 座臓器病態外科学 森下靖雄教授および御協力頂きまし た関係諸氏に深謝いたします。 